\title{
PENGARUH MEDIA SOSIAL DALAM PENINGKATAN PENGETAHUAN DAN SIKAP SISWA PEROKOK TERHADAP PENCEGAHAN STAIN GIGI DI SMA NEGERI 1 SEI LEPAN KABUPATEN LANGKAT TAHUN 2019
}

\section{Social Media Effect in Increasing Knowledge and Attitudes of Smoking Students on Dental Staining Prevention in SMA Negeri 1 Sei lepan Langkat Regency 2019}

\author{
Adi Wika Prasetya ${ }^{1}$, Kintoko Rochadi ${ }^{2}$, Namora Lumongga ${ }^{3}$ \\ 1,2,3 Fakultas Kesehatan Masyarakat Universitas Sumatera Utara
}

\begin{abstract}
Abstrak
Dalam hal mencegah perilaku merokok pada remaja dapat dilakukan tindakan promotif melalui pendidikan kesehatan dengan menggunakan media sosial. Stain gigi adalah noda coklat pada permukaan gigi dan merupakan salah satu masalah estetik. Tujuan penelitian untuk menganalisis pengaruh media sosial dalam peningkatan pengetahuan dan sikap siswa perokok terhadap pencegahan stain gigi di SMA Negeri 1 Sei Lepan, Kabupaten Langkat. Jenis penelitian adalah quasi experiment dengan rancangan pretest dan posttest. Penelitian dilaksanakan di SMA Negeri 1 Sei Lepan Kabupaten Langkat, total keseluruhan sampel dalam penelitian ini adalah 76 orang, yaitu kelompok intervensi dan kontrol dengan kuesioner. Hasil penelitian menunjukkan media sosial secara signifikan $(p<0,05)$ memberikan pengaruh terhadap tingkat pengetahuan dan sikap siswa perokok terhadap pencegahan stain gigi, dibandingkan remaja yang tidak dilakukan intervensi dengan media sosial. Media sosial lebih efektif meningkatkan pengetahuan dan sikap siswa perokok terhadap pencegahan stain gigi. Disarankan kepada orang tua untuk menghindari perilaku merokok didepan anak dan memberikan edukasi tentang bahaya merokok yang dapat merusak gigi, pihak sekolah meningkatkan kerja sama dengan orang tua untuk membicarakan perkembangan akademik dan perilaku siswa.
\end{abstract}

Kata Kunci: Media Sosial, Merokok, Stain gigi

\begin{abstract}
In terms of preventing smoking behavior in adolescents, promotive action can be carried out through health education by using social media to provide information and education to improve good knowledge and attitudes on smoking prevention. Dental staining is a brown stain on the tooth surface and is one of the aesthetic problems. This research aims to analyze the effect of social media in improving the knowledge and attitude of smoking students on dental staining prevention in SMA Negeri 1 Sei Lepan, Langkat Regency.This research was a quasi-experiment with pretest and posttest design. Research was done in SMA Negeri 1 Sei Lepan Langkat Regency, with total sample 76 students divided into two groups, treatment group and control group was done using questionnaire. Results showed that social media significantly $(p<0.05)$ affect knowledge and attitude of smoking students on dental staining prevention, compared to control group, which didn't receive social media intervention. Social media are more effective in improving knowledge and attitude of smoking students on dental staining prevention. It is recommended for parents to avoid smoking behavior in front of children and provide education about smoking hazard that can deteriorate teeth, for teachers to cooperate with parents to discuss children academic and behavior development
\end{abstract}

Keywords: Social Media, Smoking, Dental Stain.

Korespondensi : Adi Wika Prasetya

Email : adiwikaprasetya6161@gmail.com 


\section{PENDAHULUAN}

Merokok merupakan salah satu kebiasaan yang ditemui dalam kehidupan sehari-hari. Gaya hidup atau lifestyle ini menarik sebagai suatu masalah kesehatan. Hasil studi menunjukkan bahwa perokok berat telah memulai kebiasaannya ini sejak berusia belasan tahun, dan hampir tidak ada perokok berat yang baru memulai merokok pada saat dewasa. Masa muda dijadikan penentu bahwa dewasanya menjadi perokok atau tidak (14). Data World Health Organization (2013), seluruh dunia diperkirakan terdapat sebanyak 1,26 miliar perokok dan lebih dari 200 juta di antaranya adalah remaja, pada remaja pria didapat 55\% dari mereka yang termotivasi terhadap perilaku merokok dipengaruhi oleh iklan dan lingkungan. Anak yang memiliki teman perokok sembilan kali lebih rentan untuk mencoba merokok. Begitu mencoba mereka menjadi kecanduan, meskipun telah di informasikan di kemasan rokok atau setiap iklan rokok bahwa merokok dapat menyebabkan kanker, serangan jantung, impotensi, gangguan kehamilan dan janin. (14). Data Riset Kesehatan Dasar (Riskesdas) Kementrian Kesehatan (Kemenkes) tahun 2018, prevalensi perokok usia 15 tahun keatas mencapai 33,8\%. Data Global Youth Tobacco Survey 2014 (GYTS 2014) menyebutkan 20,3\% anak sekolah merokok (Laki-laki 36\%, perempuan $4,3 \%$ ). Walaupun proporsi perokok perempuan lebih rendah dibandingkan laki-laki, namun terjadi peningkatan sebanyak 5 kali lipat dari 1,7\% (1995) menjadi 6,7\% (2013) (6). Hasil Riskesdas terakhir juga menyebutkan bahwa perilaku merokok pada remaja meningkat dari sebelumnya yakni dari 7,2 persen (Riskesdas 2013), 8,8 persen (Sirkesnas 2016), dan kini 9,1 persen
(Riskesdas 2018). Prevalensi nasional merokok di usia lebih dari 10 tahun secara nasional sebesar 28,8\% (Riskesdas 2018). Merokok tidak hanya menimbulkan efek secara sistemik, tetapi juga dapat menyebabkan timbulnya kondisi patologis di rongga mulut. Gigi dan jaringan lunak rongga mulut, merupakan bagian yang dapat mengalami kerusakan akibat rokok. Penyakit periodontal, karies, stain gigi, kehilangan gigi, resesi gingiva, lesi prekanker, kanker mulut, adalah kasus-kasus yang dapat timbul akibat kebiasaan merokok (9). Stain gigi adalah deposit berpigmen pada permukaan gigi dan merupakan salah satu masalah estetik. Kebiasaan merokok meningkatkan salah satu faktor penyebab terjadinya beberapa kelainan di rongga mulut, salah satunya dapat menimbulkan stain gigi pada permukaan gigi. Rokok mengandung tiga macam bahan kimia yang berbahaya yaitu tar, nikotin dan karbonmonoksida. Temperatur asap rokok yang tinggi dapat menyebabkan gangguan lokal di dalam rongga mulut. Pada jaringan gigi, rokok dapat menyebabkan diskolorasi pada permukaan email, terutama pada servikal gigi. Stain pada gigi disebabkan karena hasil pembakaran tembakau berupa tar (8). Gangguan yang diakibatkan oleh stain terutama adalah masalah estetik atau penampilan akibat rokok. Endapan stain yang menebal dapat membuat kasar permukaan gigi yang selanjutnya akan menyebabkan penumpukan plak sehingga mengiritasi gusi didekatnya. Stain tertentu, mengindiikasikan dilakukannya evaluasi kebersihan mulut dan perawatan yang berkaitan dengan kebersihan mulut (9). Media pendidikan kesehatan sebagai faktor eksternal dapat dimanfaatkan untuk meningkatkan efisiensi belajar karena mempunyai potensi atau kemampuan 
untuk merangsang terjadinya proses belajar. Seseorang menyerap informasi $10 \%$ dari yang dibaca, $20 \%$ dari yang didengar, 30\% dari yang dilihat, 50\% dari yang dilihat dan didengar, $70 \%$ dari yang dikatakan, dan $90 \%$ dari yang dikatakan dan dilakukan. Dapat disimpulkan bahwa semakin banyak indera yang terlibat dalam proses belajar maka akan semakin banyak informasi yang bisa diserap (7). Efek media yang diterima oleh penerima berupa gambar, ide, tema dan cerita. Penerima efek media tidak hanya sebagai penerima pasif, namun juga sebagai pencari aktif dan pengguna informasi (4). Media sosial mengajak siapa saja yang tertarik untuk berpartisipasi dengan memberi feedback secara terbuka, memberi komentar, serta membagi informasi dalam waktu yang cepat dan tak terbatas. Tidak dapat dipungkiri bahwa media sosial mempunyai pengaruh yang besar dalam kehidupan seseorang (2). Seseorang yang awalnya kecil bisa menjadi besar dengan media sosial, atau sebaliknya. Bagi masyarakat khususnya kalangan remaja, media sosial sudah menjadi candu yang membuat penggunanya tiada hari tanpa membuka media sosial (11). Sebagai target sasaran penyuluhan, remaja perlu mendapatkan pendidikan kesehatan tentang bahaya merokok, didasari pada asumsi bahwa secara psikologis karakteristik kepribadian remaja bersifat labil. Oleh karenanya dalam rangka merubah persepsi yang keliru tentang merokok perlu dicegah dengan pemberian informasi tentang bahaya merokok dalam bentuk audio visual di media sosial (15). Adapun tujuan dari pendidikan kesehatan tentang bahaya merokok di kalangan remaja ini adalah untuk meningkatkan pengetahuan dan pemahaman remaja terhadap bahaya merokok, serta memotivasi dan menumbuhkan kesadaran terhadap tanggung jawab para remaja dalam membentengi diri, lingkungan, pergaulan dari bahaya merokok (12). Membahas tentang media sosial tentu tidak lepas dengan nama-nama media sosial mainstream saat ini, sebut saja Facebook, Twitter, Instagram, Youtube, sampai ke yang berbasis chatting seperti Whatsapp, Line, Kakao Talk, Telegram, dst. Sangat banyak dan beragam jenisnya. Untuk itu mari kita ulas materi seputar fenomena perilaku masyarakat terhadap Media Sosial di Indonesia. Total pengguna sosial media di Indonesia mencapai 150 juta pengguna, ini berarti mayoritas penggunaan internet untuk bersosialisasi melalui media sosial. Jumlah pengguna media sosial ini mencapai $56 \%$ dari jumlah total penduduk Indonesia, dengan pengguna berbasis mobilenya mencapai 130 juta (16). Data Hootsuite 2019, Facebook di posisi kedua jejaring sosial setelah Youtube dengan angka 130 juta pengguna. Facebook dikenal mudah dalam penggunaannya. Fitur yang sederhana membuat Facebook bertahan sebagai sosial media yang lama dipakai dikalangan masyarakat menengah. Whatsapp menempati posisi teratas aplikasi pesan yang digunakan masyarakat pada saat ini. Kini fitur di Whatsapp juga sudah diperbarui seperti layaknya kita menggunakan media sosial, seperti bisa memperbarui status (viewed update). Data Riskesdas tahun 2013, jumlah perokok di provinsi Sumatera Utara mencapai 29,7\%, untuk nasional prevalensi perokok laki-laki sebesar 54,1\% sedangkan perokok saat ini di Sumatera Utara 35,7\%. Rata-rata jumlah batang rokok yang dihisap tiap hari oleh lebih dari separuh $(52,3 \%)$ perokok adalah $1-10$ batang. Di Kabupaten langkat, Proporsi perokok pada laki-laki usia 10 tahun keatas dengan konsumsi rokok 1-2 
batang per hari 50,7\%. Kecamatan Sei Lepan, Kabupaten Langkat merupakan daerah kerja dari peneliti sebagai tenaga kesehatan. Melihat kondisi di lapangan, banyak didapatkan siswa perokok pada usia remaja. Penelitian - penelitian sebelumnya menerangkan pengaruh media yang digunakan dalam rangka peningkatan pengetahuan tentang bahaya merokok. Melihat kondisi ini, peneliti tertarik melakukan penelitian terhadap siswa perokok untuk dilihat pengetahuannya tentang bahaya merokok melalui media sosial sebagai sarana dalam penyampaian informasi. Intensitas para siswa-siswi dalam menggunakan media sosial setiap hari cukup tinggi, ini menjadi salah satu alternatif metode dalam memberikan informasi. Melihat fenomena diatas, maka perlu diberikan tambahan informasi untuk meningkatkan pengetahuan dan sikap remaja tentang bahaya merokok dengan metode yang berbeda. Berdasarkan penjelasan diatas, penulis tertarik untuk melakukan penelitian dengan judul "Pengaruh Media Sosial Dalam Peningkatan Pengetahuan Dan Sikap Siswa Perokok Terhadap Pencegahan Stain Gigi di SMA Negeri 1 Sei Lepan Kabupaten Langkat Tahun 2019”.

\section{METODE}

Penelitian ini merupakan jenis penelitian kuantitatif, dengan desain penelitian menggunakan metode kuasi eksperimen (Quasi Experiment), dengan rancangan penelitian yang digunakan adalah rancangan pre-test and post-test group design. Penelitian dilaksanakan di SMA Negeri 1 Sei Lepan Kabupaten Langkat, dimulai pada bulan Juni tahun 2019 sampai dengan selesai. Populasi adalah semua siswa Laki - laki di Sekolah Menengah Atas Negeri 1 Kecamatan Sei Lepan
Kabupaten Langkat. Sampel yang digunakan dalam penelitian ini adalah sebanyak 76 orang yang dibagi dua menjadi kelompok intervensi dan kelompok kontrol. Untuk kelompok intervensi diberikan perlakuan pemberian intervensi di media sosial facebook setiap hari selama 14 hari. Teori evaluasi bahwa jarak antara dua pengukuran minimal 2 minggu untuk pengetahuan dan sikap, minimal 1 bulan untuk perilaku (3). Hal ini sesuai juga dengan konsep sleeper effect yang dikemukakan oleh Bringham bahwa orang masih ingat isi pesan yang disampaikan dalam waktu 10-14 hari setelah pesan itu disampaikan (1). Data yang dikumpulkan oleh peneliti secara langsung dari sumber datanya dengan metode wawancara kepada responden, kuesioner diisi oleh peneliti. Metode analisis data dalam penelitian ini menggunakan statistik.

\section{HASIL PENELITIAN}

Tingkat pengetahuan pada siswa perokok sebelum (Pre test) diberikan media sosial diketahui dari 38 responden, dapat dilihat pengetahuan siswa terhadap pencegahan stain gigi memiliki pengetahuan buruk sebanyak 27 orang $(71,1 \%)$ dan minoritas pengetahuan siswa perokok terhadap pencegahan stain gigi memiliki pengetahuan cukup sebanyak 11 orang $(28,9 \%)$. Berdasarkan sikap responden dapat dilihat bahwa mayoritas sikap pada siswa perokok sebelum (Pre test) diberikan media sosial diketahui dari 38 responden, dapat dilihat sikap siswa terhadap pencegahan stain gigi memiliki sikap buruk sebanyak 30 orang $(78,9 \%)$ dan minoritas sikap siswa perokok terhadap pencegahan stain gigi memiliki sikap cukup sebanyak 8 orang $(21,1 \%)$. 
Tabel 1. Distribusi Frekuensi Responden Kelompok 1 (Intervensi) Sebelum Diberikan Media Sosial (Pre-Test) Pada Siswa Perokok di SMA Negeri 1 Sei Lepan Kabupaten Langkat Tahun 2019

\begin{tabular}{|c|c|c|}
\hline Variabel & $\begin{array}{l}\text { Frekuensi } \\
\text { ( n ) }\end{array}$ & $\begin{array}{c}\text { Persentase } \\
(\%)\end{array}$ \\
\hline \multicolumn{3}{|l|}{ Pengetahuan } \\
\hline 1. Buruk & 27 & 71,1 \\
\hline 2. Cukup & 11 & 28,9 \\
\hline 3. Tinggi & 0 & 0 \\
\hline Total & 38 & 100 \\
\hline \multicolumn{3}{|l|}{ Sikap } \\
\hline 1. Buruk & 30 & 78,9 \\
\hline 2. Cukup & 8 & 21,1 \\
\hline 3. Baik & 0 & 0 \\
\hline Total & 38 & 100 \\
\hline
\end{tabular}

Mayoritas tingkat pengetahuan pada siswa perokok sebelum (Pre test) tanpa intervensi diketahui dari 38 responden, dapat dilihat pengetahuan siswa terhadap pencegahan stain gigi memiliki pengetahuan buruk sebanyak 26 orang $(68,4 \%)$ dan minoritas pengetahuan siswa perokok terhadap pencegahan stain gigi memiliki pengetahuan cukup sebanyak 12 orang (31,6\%). Berdasarkan sikap responden dapat dilihat bahwa mayoritas sikap pada siswa perokok sebelum (Pre test) tanpa intervensi diketahui dari 38 responden, dapat dilihat sikap siswa terhadap pencegahan stain gigi memiliki sikap buruk sebanyak 29 orang $(76,3 \%)$ dan minoritas sikap siswa perokok terhadap pencegahan stain gigi memiliki sikap cukup sebanyak 9 orang $(23,7 \%)$.

Tabel 2. Distribusi Frekuensi Responden Kelompok 2 (Kontrol) (Pre-Test) Tanpa Intervensi Pada Siswa Perokok di SMA Negeri 1 Sei Lepan Kabupaten Langkat Tahun 2019

\begin{tabular}{|c|c|c|}
\hline Variabel & $\begin{array}{c}\text { Frekuensi } \\
(\mathbf{n})\end{array}$ & $\begin{array}{c}\text { Persentase } \\
(\%)\end{array}$ \\
\hline \multicolumn{3}{|l|}{ Pengetahuan } \\
\hline 1. Buruk & 26 & 68,4 \\
\hline 2. Cukup & 12 & 31,6 \\
\hline 3. Tinggi & 0 & 0 \\
\hline Total & 38 & 100 \\
\hline \multicolumn{3}{|l|}{ Sikap } \\
\hline 1. Buruk & 29 & 76,3 \\
\hline 2. Cukup & 9 & 23,7 \\
\hline 3. Baik & 0 & 0 \\
\hline Total & 38 & 100 \\
\hline
\end{tabular}


Tingkat pengetahuan pada siswa perokok setelah (Post test) diberikan media sosial diketahui dari 38 responden, dapat dilihat pengetahuan siswa terhadap pencegahan stain gigi memiliki pengetahuan tinggi sebanyak 27 orang $(71,1 \%)$ dan minoritas pengetahuan siswa perokok terhadap pencegahan stain gigi memiliki pengetahuan cukup sebanyak 11 orang $(28,9 \%)$. Berdasarkan sikap responden dapat dilihat bahwa mayoritas sikap pada siswa perokok sesudah (Post test) diberikan media sosial diketahui dari 38 responden, dapat dilihat sikap siswa terhadap pencegahan stain gigi memiliki sikap baik sebanyak 32 orang $(84,2 \%)$ dan minoritas sikap siswa perokok terhadap pencegahan stain gigi memiliki sikap cukup sebanyak 6 orang $(15,8 \%)$.

Tabel 3. Distribusi Frekuensi Responden Kelompok 1 (Intervensi) Sesudah Diberikan Media Sosial (Post-Test) Pada Siswa Perokok di SMA Negeri 1 Sei Lepan Kabupaten Langkat Tahun 2019

\begin{tabular}{|c|c|c|}
\hline Variabel & $\begin{array}{c}\text { Frekuensi } \\
\text { (n) }\end{array}$ & $\begin{array}{c}\text { Persentase } \\
(\%)\end{array}$ \\
\hline \multicolumn{3}{|l|}{ Pengetahuan } \\
\hline 1. Buruk & 0 & 0 \\
\hline 2. Cukup & 11 & 28,9 \\
\hline 3. Tinggi & 27 & 71,1 \\
\hline Total & 38 & 100 \\
\hline \multicolumn{3}{|l|}{ Sikap } \\
\hline 1. Buruk & 0 & 0 \\
\hline 2. Cukup & 6 & 15,8 \\
\hline 3. Baik & 32 & 84,2 \\
\hline Total & 38 & 100 \\
\hline
\end{tabular}

Pengetahuan pada siswa perokok setelah (Post test) tanpa intervensi diketahui dari 38 responden, dapat dilihat pengetahuan siswa terhadap pencegahan stain gigi memiliki pengetahuan buruk sebanyak 23 orang $(60,6 \%)$ dan minoritas pengetahuan siswa perokok terhadap pencegahan stain gigi memiliki pengetahuan cukup sebanyak 15 orang $(39,5 \%)$. Berdasarkan sikap responden dapat dilihat bahwa mayoritas sikap pada siswa perokok sesudah (Post test) tanpa intervensi diketahui dari 38 responden, dapat dilihat sikap siswa terhadap pencegahan stain gigi memiliki sikap buruk sebanyak 27 orang $(71,1 \%)$ dan minoritas sikap siswa perokok terhadap pencegahan stain gigi memiliki sikap cukup sebanyak 11 orang $(28,9 \%)$. 
Tabel 4. Distribusi Frekuensi Responden Kelompok 2 (Kontrol) (Post-Test) Tanpa Intervensi Pada Siswa Perokok di SMA Negeri 1 Sei Lepan Kabupaten Langkat Tahun 2019

\begin{tabular}{|c|c|c|}
\hline Variabel & $\begin{array}{c}\text { Frekuensi } \\
\text { (n) }\end{array}$ & $\begin{array}{c}\text { Persentase } \\
(\%)\end{array}$ \\
\hline \multicolumn{3}{|l|}{ Pengetahuan } \\
\hline 1. Buruk & 23 & 60,5 \\
\hline 2. Cukup & 15 & 39,5 \\
\hline 3. Tinggi & 0 & 0 \\
\hline Total & 38 & 100 \\
\hline \multicolumn{3}{|l|}{ Sikap } \\
\hline 1. Buruk & 27 & 71,1 \\
\hline 2. Cukup & 11 & 28,9 \\
\hline 3. Baik & 0 & 0 \\
\hline Total & 38 & 100 \\
\hline
\end{tabular}

\section{PEMBAHASAN}

Berdasarkan hasil penelitian yang dilakukan di SMA Negeri 1 Sei Lepan Kabupaten Langkat sebelum (pre-test) diberikan media sosial pada siswa perokok kelompok 1 (intervensi) mayoritas siswa perokok memiliki pengetahuan buruk sebanyak 27 orang $(71,1 \%)$. Berdasarkan hasil penelitian yang dilakukan di SMA Negeri 1 Sei Lepan Kabupaten Langkat sesudah (post-test) diberikan media sosial pada siswa perokok kelompok 1 (intervensi) mayoritas siswa perokok memiliki pengetahuan tinggi sebanyak 27 orang $(71,1 \%)$. Berdasarkan hasil uji wilcoxon, diperoleh nilai ( $\mathrm{p}$ value $=0,000)<$ 0,05 yang berarti bahwa ada pengaruh pemberian media sosial terhadap peningkatan pengetahuan dalam pencegahan stain gigi di SMA Negeri 1 Sei Lepan Kabupaten Langkat Tahun 2019. Pengetahuan adalah hasil penginderaan manusia, atau hasil tahu seseorang terhadap objek melalui indera yang dimilikinya (mata, hidung, telinga, dan sebagainya). Dengan sendirinya pada waktu penginderaan sampai menghasilkan pengetahuan tersebut sangat dipengaruhi intensitas perhatian dan persepsi terhadap objek. Sebagian besar pengetahuan seseorang diperoleh melalui indera pendengaran (telinga), dan indera penglihatan (mata) (13). Pengetahuan setelah dilakukannya intervensi menggunakan media sosial terlihat lebih tinggi dibandingkan pengetahuan sebelum intervensi, Pengetahuan yang dimaksud dalam hal ini adalah pengetahuan setelah intervensi menggunakan media sosial promosi kesehatan tentang segala sesuatu yang berhubungan dengan rokok dan bahayanya yang meliputi: kandungan zat utama dalam rokok, bahaya kesehatan yang ditimbulkan oleh rokok, perbedaan perokok pasif dan perokok aktif serta akibat rokok pada organ tubuh (13). Hasil penelitian ini menunjukkan terjadi peningkatan pengetahuan sebelum (pretest) dan sesudah (post-test) diberikan media sosial. Penelitian ini sejalan dengan penelian yang dilakukan tahun 2018 di Pekanbaru yang menyatakan ada pengaruh penggunaan media sosial terhadap peningkatan pengetahuan remaja perokok 
dalam pencegahan stain gigi. Media sosial melalui internet memiliki potensi besar untuk melakukan promosi kesehatan dan intervensi kesehatan lainnya, dan lebih mudah untuk menyentuh sasaran pada setiap levelnya (5). Hasil penelitian yang dilakukan di SMA Negeri 1 Sei Lepan Kabupaten Langkat sebelum (pre- test) diberikan media sosial pada siswa perokok kelompok 1 (intervensi) mayoritas siswa perokok memiliki sikap buruk sebanyak 30 orang (78,9\%). Berdasarkan hasil penelitian yang dilakukan di SMA Negeri 1 Sei Lepan Kabupaten Langkat sesudah (post- test) diberikan media sosial pada siswa perokok kelompok I (intervensi) mayoritas siswa perokok memiliki sikap baik sebanyak 32 orang (84,2\%). Berdasarkan hasil uji wilcoxon, diperoleh nilai ( $\mathrm{p}$ value $=0,000)<0,05$ yang berarti bahwa ada pengaruh pemberian media sosial terhadap peningkatan sikap dalam pencegahan stain gigi di SMA Negeri 1 Sei Lepan Kabupaten Langkat Tahun 2019. Sikap (attitude) merupakan "reaksi atau respon yang masih tertutup dari seseorang terhadap suatu stimulus atau objek". Sikap merupakan reaksi atau respon yang masih tertutup terhadap suatu stimulus atau obyek. Manifestasi sikap tidak dapat dilihat, tetapi hanya dapat ditaksirkan. Sikap merupakan kecenderungan yang berasal dari dalam diri individu untuk berkelakuan dengan pola-pola tertentu, terhadap suatu obyek akibat pendirian dan perasaan terhadap obyek tersebut. Hasil penelitian ini menunjukkan terjadi peningkatan sikap sebelum (pre-test) dan sesudah (post-test) diberikan media sosial. Penelitian ini sejalan dengan penelitian Saskia tahun 2014 menunjukan bahwa terdapat pengaruh yang signifikan pemberian penyuluhan terhadap sikap siswa tentang bahaya rokok. Penelitian lain menyebutkan bahwa ada pengaruh penyuluhan dengan metode pemberian media sosial tentang bahaya rokok terhadap perubahan sikap perokok aktif di desa Tirtajaya kecamatan Bajuin Kabupaten Tanah Laut Tahun 2014 nilai $\mathrm{p}$ diperoleh $<0,05$. Sikap adalah suatu bentuk evaluasi atau reaksi perasaan. Sikap seseorang terhadap suatu obyek adalah perasaan mendukung atau memihak (favorable) maupun perasaan tidak mendukung atau tidak memihak (unfaforable) pada obyek tersebut. Perubahan sikap tergantung dari cara atau metode yang digunakan dalam menyampaikan pesan atau program (10). Berdasarkan hasil penelitian yang dilakukan di SMA Negeri 1 Sei Lepan Kabupaten Langkat sebelum (pre- test) tanpa diberikan intervensi pemberian media sosial pada siswa perokok kelompok II (kontrol) mayoritas siswa perokok memiliki pengetahuan buruk sebanyak 26 orang (68,4\%). Berdasarkan hasil penelitian yang dilakukan di SMA Negeri 1 Sei Lepan Kabupaten Langkat sesudah (post- test) tanpa diberikan intervensi pemberian media sosial pada siswa perokok kelompok 2 (kontrol) mayoritas siswa perokok memiliki pengetahuan buruk sebanyak 23 orang (60,5\%). Berdasarkan hasil uji wilcoxon, diperoleh nilai $(p$ value $=0,083)>0,05$ yang berarti bahwa tidak terdapat perbedaan bermakna antara kelompok pre-test dan post-test terhadap peningkatan pengetahuan terhadap pencegahan stain gigi tanpa pemberian intervensi media sosial, sehingga dapat disimpulkan bahwa ada pengaruh media sosial dalam peningkatan pengetahuan siswa perokok terhadap pencegahan stain gigi di SMA Negeri 1 Sei Lepan Kabupaten Langkat Tahun 2019. 


\section{KESIMPULAN DAN SARAN}

Tingkat pengetahuan dan sikap sebelum (pre-test) diberikan intervensi pemberian media sosial pada siswa perokok terhadap pencegahan stain gigi di SMA Negeri 1 Sei Lepan Kabupaten Langkat Tahun 2019 pada kelompok I (intervensi) didominasi memiliki kategori pengetahuan dan sikap buruk. Terdapat perbedaan pengetahuan dan sikap pada siswa setelah diberikan intervensi pemberian informasi di media sosial pada siswa perokok (post-test). Bagi responden yang memiliki pengetahuan terkait bahaya merokok diharapkan dapat memberikan informasi kepada teman mereka agar dapat mengurangi konsumsi rokok dan perlu ditingkatkan kesadaran pengetahuan tentang bahaya merokok, pihak sekolah memberlakukan Kawasan Tanpa Rokok (KTR), bagi peneliti selanjutnya diharapkan dapat dijadikan referensi sebagai salah satu media pendidikan kesehatan tetapi perlu ditambahkan pengalaman responden terkait bahaya merokok.

\section{DAFTAR PUSTAKA}

1. Azwar, S. 2012. Sikap Manusia: Teori dan Pengukurannya. Jakarta: EGC

2. Akram, W. Kumar, R. 2017. A Study on Positive and Negative Effects of Social Media on Society. International Journal of Computer Sciences and Engineering. Vol.5(10), Oct 2017, EISSN: 2347-2693.

3. Budiharto. (2010). Pengantar Ilmu perilaku Kesehatan dan Pendidikan Kesehatan. Jakarta: EGC.

4. Glanz K, B K Rime, Viswanath. 2008. Health Behavior And Health Education: Theory, Research, and Practice 4th Edition. San Fransisco, USA.
5. Leonita1 E dan Jalinus N, 2018. Peran Media Sosial dalam Upaya Promosi Kesehatan: Tinjauan Literatur. Jurnal Inovasi Vokasional dan Teknologi. Fakultas Teknik, Universitas Negeri Padang. Volume 18(2)

6. Martiany D. 2016. Kendali Jumlah Perokok Untuk Melindungi Kesehatan Perempuan. Majalah Info Singkat Kesejahteraan Sosial. Vol. VIII, No. 16

7. Nurhidayah, Rika E. 2010. Ilmu Perilaku dan Pendidikan Kesehatan untuk Perawat. Medan: USU Press.

8. Oktanauli P. 2017. Distribusi Frekuensi Perubahan Warna Email Gigi Pada Perokok. Cakradonya Dent J. 9(2):116-120,

9. Putri, CH., Lampu, B.S. 2014. Gambaran Pengetahuan Stain Gigi Pada Perokok di Kelurahan Batu Lingkungan V. e GiGi J. 2(2).

10. Saskia RR, 2015. Penyuluhan tentang bahaya merokok terhadap sikap siswa kelas VI di SDN Gedog Wetan Turen Kabupaten Malang: Malang.

11. Secsio Wilga, R., Nunung R. 2016. Pengaruh Media Sosial Terhadap Perilaku Remaja. Prosiding KS. 3(1). 47-51. ISSN : 2442-4480

12. Setiawati. 2008. Pendidikan Kesehatan.Jakarta: Trans Info Media.

13. Sulastri dan Rindu, 2019. Perbedaan Pengetahuan dan Sikap Remaja Sebelum dan Sesudah Promosi kesehatan Tentang Dampak Rokok. Program Studi Ilmu kesehatan Masyarakat, Sekolah Tinggi Ilmu Kesehatan Indonesia Maju 2019.

14. Syair Abdul, 2009. Pengantar rokok dan remaja, Jakarta: Salemba

15. Siddiqui, S. Social Media its Impact with Positive and Negative Aspects. International Journal of Computer 
Applications Technology and Research Volume 5- Issue 2, 71 - 75, 2016, ISSN:- 2319-8656

16. Websindo.2019. Indonesia Digital 2019 : Media Sosial.
Tersedia

https://websindo.com/indonesiadigital-2019-media-sosial/ 